\title{
Ethical Principles on the Freedom of Speech and Expression in the Developed and Developing Countries
}

\author{
Alim A* \\ Department of Law, University of Rajshahi, Bangladesh
}

*Corresponding author: Abdul Alim, Professor Department of Law, University of Rajshahi, 6205, Bangladesh, Tel: 88-01714896132; Email: alimlaw05@gmail.com

\section{Research Article \\ Volume 4 Issue 1}

Received Date: March 09, 2021

Published Date: March 26, 2021

DOI: $10.23880 / a b c a-16000172$

\section{Abstract}

The First Amendment to the United States Constitution is an essential part of the Bill of Rights. The amendment prohibits making of any law respecting an establishment of religion, obstructing the free exercise of religion, infringing on the freedom of speech, infringing on the freedom of the press, interfering peoples assembling rights in a peaceful manner or prohibiting the petitioning for a governmental remedy of grievances. The guarantees of this Bill of Rights were subject to the limitation imposed by the free speech and press provisions of the First Amendment to the US Constitution as interpreted and applied by the Supreme Court and other courts. The United States and India are the largest democratic country and almost have similar free speech provisions in their Constitutions. This Article is intended to present the free speech provisions of the American and Indian Constitution as a basic fundamental right of human being. It is also to be examined that what is the role of Supreme Court in interpreting the freedom of speech and expression provisions. The study also tries to incorporate the comparison between the looms of both countries as far as freedom of speech is disturbed.

Keywords: Freedom of Speech; Freedom of Expression; Comparative Study; Indian Supreme Court; US Supreme Court

\section{Introduction}

"I do not agree with a word you say, but I will defend to the death your right to say it" Voltaire.

Silence is an ocean. Speech is a river. Silence is the language of God [1]. To the Sherlock Holmes observation, in a silent mode dog's failure to bark during the night was significant and suspicious [2]. People are sovereign in a democratic republican form of government [3]. It seems selfevident that the electoral process can have meaning only if voters can engage in a frank and vigorous discussion about the merits of the candidates, including criticism of incumbent government officials. If the people, not government officials, are sovereign, it should follow that those officials have no right to silence their critics. The United States Constitution is what the courts say it is; presidents, congressmen, State officials, bureaucrats, and all other Americans are obligated to act in accordance with court interpretations of the Federal and State Constitutions. However, in Nebraska Press Association v. Stuart (1976) [4], the United States Supreme Court held that State courts were bound by the Supreme Court decisions on judicial matters [5]. If the courts interpret the Constitution to say that judges may not exclude the press from open hearings, no judge may do so [6]. Since Marbury v. Madison in 1803 [7], United States courts have asserted the right to be authoritative interpreters of the Constitution, and the other political bodies have conceded them that power. At present, the role of the Supreme Court is the arbitrator of the Constitution announces with regard to the powers of the Executive and Legislative branch. The main feature of the 1st amendment right is "Congress shall make no law respecting an establishment of religion, or prohibiting the free exercise thereof; or abridging the freedom of speech, or of the press, or the right of the people peacefully to assemble, and to petition the Government for a redress of grievances" [8]. This 
Article is projected to analyze the free speech provisions of the American and Indian Constitution as a basic fundamental right of human beings. It is also to be examined that what is the role of the Supreme Court in interpreting the freedom of speech and expression provisions. The study also aims to make a comparison between the approaches of the countries US and India as far as freedom of speech is concerned.

\section{Freedom of Expression in Bangladesh}

A writer named Mushtaq Ahmed, who had been locked up under the controversial Digital Security Act for over nine months in Bangladesh and he was denied bail six times and he died in prison [9]. The case is a collection of 10 social media posts and links with a cartoons made before the pandemic. It was a mock about the health care system of the country. The mass people have urged a transparent and independent probe into the death in custody of writer Mushtaq Ahmed in a Bangladesh prison on February 25. They also said it was a constructive criticism, not to propagate disinformation. Now academician, students, lawyers, rights activists, and journalists have demanded the immediate release of people who were arrested under the Digital Security Act, and the repeal of the act immediately.

\section{Media and Social Literacy}

Freedom of speech is to defend the right of all citizens to appreciate political issues so that they can participate in the horizontal working of democracy. Freedom of the press is the heart of a State and also in political institutions. The Facebook Company is equipped with proactive tools to detect hate speech, rumors, and related content. But the steps have taken are not enough to tackle the millions of texts and images uploaded by almost two billion users every day. Freedom of the press, like freedom of speech, is subject to restrictions on the basis such as defamation law. Media literacy awareness program is very much essential and to introduce the concept of media literacy to a textbook that people could think effectively help the younger generations to maintain responsible behavior on social media as well as the police, lawyers, Judge's legal mind could extend. Facebook would not able to tackle these situations if they are not aware of local laws also that considered the nature of society's customs. American judiciary has approved content-based regulation. In various cases of the Supreme Court carried out the content-based regulation of television and radio.

\section{Freedom of Speech in India}

The constitutional significance of the liberty of speech consists within the Preamble of the Constitution and is renovated as fundamental and right in Article 19(1) (a) as "freedom of speech and expression". Unlike the U.S. Constitution, the provisions of Indian Constitution obviously set out limitations on free speech. The liberty of speech guarantee under Article 19(1) (a) will be subject to reasonable state restriction within the interest of decency, or morality. Moreover, it's important to notice that the liberty of one must not offend the freedom of others. In A.K. Gopalan case, Justice Patanjali Shastri observed, "Man as a rational being desires to do many things, but in a civil society his desires will have to be controlled with the exercise of similar desires by other individuals". Therefore, it includes the proper to propagate one's views through the medium or through the other channel e.g. the Facebook, radio, and therefore the television. Every citizen of this country has the proper to air his or their views through the printing and or the electronic media subject in fact to permissible restrictions imposed under Article 19(2) of the Constitution. In sum, the elemental principle involved here is that the people's right to understand. Article 19(2) reasonable restrictions will be imposed on freedom of speech and expression within the interests of inter alia:

- The sovereignty/integrity of India;

- The protection of the State;

- Morality, or decency;

- Public order;

- Defamation; or

- Incitement to an offense.

However, the term "security" is an extremely crucial one. The term "security of the state" refers only to serious and aggravated styles of public order e.g. rebellion, waging war against the State, insurrection, and not ordinary breaches of public order and public safety, e.g. unlawful assembly, riot, disturbance.

\section{Main Features of First Amendment Rights in US}

The speech is any form of communication. This will include,

- Verbal communication

- Actions

- Written words

- $\quad$ Art and literature (painting, singing, dance)

Freedom of speech means people can speak freely, people can be free expressing an opinion. Free speech serves three values [10]:

- Advances truth and knowledge in the marketplace of ideas.

- $\quad$ Facilitates representative democracy and self-governing.

- Promotes autonomy and self-fulfillment. 
It is well understood that the right to free speech is not absolute at all times and under all circumstances. Throughout US history, the Supreme Court has time after time recognized at least two ways in which constitutionally protected the autonomy of speech is narrower than an unlimited license to talk. On the one hand, a certain form of speech, or speech in certain contexts, has been considered outside the scope of constitutional protection. The Court put forward the test for "incidental limitations on First Amendment freedoms". The First or Fourteenth Amendments prohibited Congress or the States to pass, when they have been found justified by subordinating valid governmental interests, a requirement to constitutionality which has essentially occupied a considering of the governmental interest involved. The First Amendment right is "Congress shall make no law respecting an establishment of religion, or prohibiting the free exercise thereof, or abridging the freedom of speech, or of the press; or the right of the people peaceably to assemble, and to petition the Government for a redress of grievances" [11]. First Amendment is incorporated into the Due Process Clause of the Fourteen Amendment and applies to State/Local Government. The First Amendment applies only to state actors; there is a common misconception that it prohibits anyone from limiting free speech, including private, non-governmental entities [12]. In Everson v. Board of Education (1947) [13], the Supreme Court incorporated the Establishment Clause (i.e., made it apply against the states): "in the words of Jefferson, the [First Amendment] clause against establishment of religion by law was intended to erect 'a wall of separation between church and State'. That wall must be kept high and impregnable. We could not approve the slightest breach" [14].

\section{Role of Indian Supreme Court}

Article 19 doesn't express provision for freedom of press but the basic elemental rights of the freedom of press inherently into the accurate freedom of speech and expression. In 2015 Singhal S, et al. [15] Union of India, the Supreme Court of India struck down Section 66A of the Information Technology Act, 2000 on the concern of online speech and intermediary liability in India. The Supreme Court, referring to restrictions on online speech, held that the Section wasn't saved by virtue of being a reasonable restriction on the freedom of speech under Article 19(2). Section 66A of this Act was declared unconstitutional, has continued to be used as a penalizing determine against online speech in several cases. The case is taken into account a watershed moment for online free speech in India [16]. The Court followed the U.S. judicial example that holds that "where no reasonable standards are laid down to define guilt in a Section which creates an offense, and where no clear guidance is given to either law abiding citizens or to authorities and courts, a Section which creates an offense and which is vague must be struck down as being arbitrary and unreasonable".

Rajagopal R, et al. [17] State of Madras Indian Supreme Court had extended the rule of actual malice in civil defamation cases and also the Sullivan principle was applied during this case [18]. In Indian Express Newspapers (Bombay) Private Ltd. v. Union of India [19], the Court reasoned that a government can levy taxes on the publication of newspapers, however within reasonable limits so on not go into freedom of expression. The Court accomplished with two basic principles must be borne in mind: first, newspapers benefit from the advantages of government services like all other industries and must accordingly donate an inexpensive share of government revenue through taxation; and second, the burden of taxation must not be excessive.

Khan I, et al. [20], was a health professional engaged in private practice. On March 28, 2020, Indranil made Facebook posts about the alleged wanting individual protective equipment (PPEs) supplied by the Indian Government to doctors in public hospitals who were about to COVID-19 affected patients. On the subsequent day, he was arrested under section 153A of the Indian Penal Code. Then within the police station he was subjected to lengthy interrogation, and his mobile phone and SIM card were seized. Justice I.P. Mukherjee of the Calcutta High Court delivered the order as one Single Bench order of the High Court operating through video conferencing. The Court held that there was no evidence that Dr. Indranil had spread "facts maliciously," like to sow fear or panic, "with a view to causing damage to another person or to the public at large or the nation." It observed that as per the protection of freedom of expression granted by Article 19 of the Constitution, the Government cannot intimidate an individual by subjecting him to lengthy police interrogations or seizures merely because that person expressed an opinion that brought disrepute to the Government.

In Tax Practitioners Assn Jain Rk, et al. [21] it had been held by court that, "Truth based on the facts should be allowed as a valid defense if courts are asked to decide contempt proceedings relating to contempt proceeding relating to a speech or an editorial or article" [22]. The Supreme Court made it clear that the freedom of speech and expression has always been considered the foremost cherished right of each and every human being. Justice Singhvi, elaborated this position with these words: "In the land of Gautam Buddha, Mahavir and Mahatma Gandhi, the freedom of speech and expression and freedom to speak one's mind have always been respected. After Independence, the Courts have zealously guarded this most precious freedom of every human being. Fair criticism of the system of administration of justice or functioning of institutions or authorities entrusted with the task of deciding rights of the parties gives an opportunity to 
the operators of the system/institution to remedy the wrong and also bring about improvements" [23].

\section{Role of US Supreme Court}

\section{Fighting Words and Threats to the Peace}

True threat requirement is that the defendant intentionally or knowingly communicates the threat. In R.A.V. v. City of St. Paul [24], the court had construed to apply only to the use of "fighting words", proscribing fighting words that arouse of anger, alarm or resentment in others on the basis of race, color, creed, religion or gender" [25]. In Chaplinsky v. New Hampshirem [26], the Court unanimously sustained a conviction under a statute proscribing "any offensive, derisive or annoying word" addressed to any person in a public place under the state court's interpretation of the statute as being bordered to "fighting words". The words or remarks made by individual have a direct tendency to cause acts of violence by the person use in a public place of words likely to cause a breach of the peace.

The Supreme Court has quoted three "reasons why threats of violence are outside the First Amendment". In Watts v. United States [27], the Court held only "true" threats are outside the First Amendment. The defendant in Watts, at a public rally, he was expressing his opposition to the military draft, said, "If they ever make me carry a rifle, the first man I want to get in my sights is L.B.J." He was accused of violating a federal statute that prohibited "any threat to take the life of or to inflict bodily harm upon the President of the United States." The Supreme Court overturned in its view. Interpreting the statute with the First Amendment clearly found that the defendant had not made a true threat, but had indulged in mere political hyperbole [28].

In NAACP v. Claiborne Hardware Co. [29], white merchants in Claiborne County, Mississippi, sued the NAACP to recover losses caused by a boycott by black citizens of their businesses, and to enjoin future boycott activity. During the boycott, NAACP Field Secretary Charles Evers had told an audience of "black people that any 'uncle toms' who broke the boycott would 'have their necks broken' by their own people" [30]. The Court think the language might have been understood as inviting an unlawful form of discipline intending to create a fear of violence and no violence had followed directly from Evers' speech. At last the Court also declared Watts, thereby implying that Evers' language also did not represent a "true threat."

\section{Doctrine of Clear and Present Danger}

Schenck v. United States [31] was the one of the first important case where Supreme Court was first requested to strike down a law violating the Free Speech Clause.

During World War I, socialists Charles Schenck and Elizabeth Baer distributed leaflets declaring that the draft violated the Thirteenth Amendment prohibition against involuntary servitude. The leaflets urged the public to disobey the draft, but advised only peaceful action. Schenck was charged with conspiracy to violate the Espionage Act of 1917 by attempting to cause insubordination in the military and to obstruct recruitment [32]. Justice Oliver Wendell Holmes concluded that courts owed greater deference to the government during wartime, even when constitutional rights were at stake. Supreme court held in this case " the question in every case is whether the words used are used in such circumstances and are of such a nature as to create a clear and present danger that they will bring about the substantive evils that Congress has a right to prevent." Thus in this case court evolved a new doctrine of "clear and present danger".

In 1984, in front of the Dallas City Hall, Gregory Lee Johnson burned an American flag where Republican National Convention was being held in Dallas, Johnson T, et al. [33] burned the flag to protest the strategies of President Ronald Reagan. He was arrested and charged with violating a Texas statute and was sentenced to one year in jail and assessed a $\$ 2,000$ fine. After the Texas Court of Criminal Appeals overturned the conviction, the case went to the Supreme Court. Johnson appealed, arguing that his actions were "symbolic speech" protected by the First Amendment. So the case name Texas v. Johnson the Supreme Court agreed to hear his case. The greater part of the Court agreed with Johnson and held that flag burning represents a form of "symbolic speech" that is protected by the First Amendment. The majority part note down that freedom of speech protects deeds that society may find very unpleasant, but society's outrage alone is not justification for suppressing free speech. In particular, the greater part noted that the Texas law discriminated upon viewpoint, i.e., although the law penalized actions, such as flag burning, that might provoke anger in others, it exclusively excepted from prosecution actions that were respectful of recognized objects, e.g., burning and burying a worn-out flag.

\section{Hate Speech and Group Libel}

In R.A.V. v. City of St. Paul, the Court, in an judgment by Justice Scalia, elucidated and qualified the clear-cut exclusions for defamation, obscenity, and fighting words. These categories of speech are not "entirely invisible to the Constitution," even though they "can, consistently with the First Amendment, be regulated because of their constitutionally proscribable content [34]. Content discrimination unrelated to that "distinctively proscribable content," however, runs entanglement of the First Amendment 
[35]. As a result, the city's bias-motivated crime ordinance, elucidated as banning the use of fighting words known to insult on the basis of race, color, creed, religion, or gender, but not on such other possible bases as political affiliation, union membership, or homosexuality, was quashed for its content discrimination. The First Amendment does not permit to impose special prohibitions on those speakers who express views on disfavored subjects [36].

In Black V, et al. [37], the Court held that its opinion in R.A.V. did not make it unconstitutional for a state to proscribe burning a cross with the intent of intimidating any person or group of persons [38]. Such a ruling out does not discriminate on the basis of a defendant's viewpoint: as a realistic matter it is not true that cross burners express their intimidating conduct solely to racial or religious minorities. The First Amendment permits Virginia to outlaw cross burnings done with the intent to intimidate because burning a cross is a predominantly dangerous form of intimidation. Instead of prohibiting all intimidating messages, Virginia may choose to control this split of intimidating messages [39].

\section{Speech on Public and Private Interest}

Freedom of Speech it expresses thoughts may not be prohibited on the ground that it hurt somebody's feelings [40]. Over the last five decades, the Court has developed a progressively more complex set of standards governing who is protected to what degree with respect to in what issues of public and private interest. Criticism of government is at the very center of the constitutionally protected area of free discussion. Criticism of the responsible for government operations must be free, lest criticism of government itself be penalized. Consequently, a extensive range of reporting about both public officials and candidates is protected. Certainly, the conduct of official duties by public officials is subject to the widest scrutiny and criticism [41]. The Court has held as well that criticism that reflects generally upon an official's integrity and honesty is protected [42].

During the Civil Rights movement of the 1960s, in the case New York Times Co. v. Sullivan [43], the New York Times published an advertisement for contributing donations to defend Martin Luther King, Jr., on lying under oath charges. The ad contained several minor realistic inaccuracies. L.B. Sullivan, who is the Public Safety Commissioner, felt that the criticism of his subordinates reflected on him. It was though he was not mentioned in the ad. Sullivan sent a written request to the Times to publicly apologize for the information, as required for a public figure to search for punitive damages in a libel action under Alabama law. Then the Times rejected and claimed that they were puzzled by the demand, Sullivan filed a libel action against the Times and a group of African
American ministers mentioned in the ad. A jury in state court awarded him $\$ 500,000$ in damages. The state Supreme Court affirmed and lastly the Times appealed.

In a unanimous opinion in US Supreme Court by Justice Brennan, the Court ruled for the Times [44]. The Court think when a statement concerns a public figure, it is not enough to show that it is false for the press to be liable for libel. As an alternative, the target of the statement must show that it was made with knowledge of or reckless disregard for its deceptiveness. The philosophy of Times and the cases following it is express on matters of public interest is protected by the First Amendment.

Robert Welch GV, et al. [45] Gertz was an attorney hired by a family to sue a police officer who had killed the family's son. American Opinion is a magazine, in this publication the John Birch Society accused Gertz of being a "Leninist" and a "Communist-fronter". The reason was he chose to represent clients who were suing a law enforcement officer. Gertz won a jury verdict and an award of $\$ 50,000$ but lost his libel suit because the trial judge found that the magazine had not violated the actual malice test for libel which the Supreme Court had established in New York Times v. Sullivan. The Court of Appeals for the Seventh Circuit affirmed the trial judge's ruling. The Court upturned the lower court decision, holding that Gertz's rights had been violated and ordering a new trial. Justice Powell declared that the application of the New York Times v. Sullivan standard in this case was improper because Gertz was neither a public official nor a public figure.

\section{False and Reckless Disregard}

Philadelphia Newspapers v. Hepps [46], in this case it was established the common law rule that defamatory statements are presumptively false must give way to the First Amendment interest that true speech on matters of public concern not be inhibited. The Gertz standard for evaluating potentially libelous speech required that "the plaintiff bear the burden of showing falsity, as well as fault, before recovering damages." In Philadelphia Newspapers, nonetheless, the Court expressly held in reserve the issue of "what standards would apply if the plaintiff sues a nonmedia defendant" [47].

Another new phenomenon was developed that "actual malice" means the defamation was published with knowledge that it was false or with reckless disregard of whether it was false [48]. Reckless disregard is not simply negligent behavior, also its publication with severe doubts as to the truth of what is uttered [49]. However, Times or Gertz standard, defamation case has the burden of proving 
by "clear and convincing" evidence, not merely by the predominance of evidence standard ordinarily borne in civil cases, that the defendant acted with knowledge of falseness or with reckless disregard. Moreover, the Court has held, a Gertz plaintiff has the burden of proving the actual falsity of the defamatory publication [50].

In Hustler Magazine, Inc. v. Falwell, [51] the Court applied the New York Times v. Sullivan standard to recovery of damages by public officials and public figures for the tort of intentional infliction of emotional distress. In November 1983, a story in the issue of Hustler Magazine featured a "parody" of an advertisement, modeled after an actual advertisement campaign, claiming that Falwell, a Fundamentalist minister and political leader, had a drunken incestuous relationship with his mother in an outhouse. Falwell sued to recover damages for libel, invasion of privacy, and intentional infliction of emotional distress. Falwell won a jury verdict on the emotional distress claim and was awarded a total of $\$ 150,000$ in damages. Hustler Magazine appealed.

In an undivided judgment the Court held that public figures, such as Jerry Falwell, may not recover for the intentional infliction of emotional distress without showing that the offending publication contained a false statement of fact which was made with "actual malice." The Court emphasized that the interest of protecting free speech, under the First Amendment, surpassed the state's concern in protecting public figures from patently offensive speech, so long as such speech could not reasonably be construed to state actual facts about its issue.

In United States v. Alvarez, [52] Justice Anthony M. Kennedy, affirmed the categories of speech, such as defamation and true threats, present a grave and imminent threat, false statements alone do not present such a threat. Justice Marshall distinguished that the rights to receive information and to personal privacy were elemental to a free society. Marshall then told that "[i]f the First Amendment means anything, it means that a State has no business telling a man, sitting alone in his own house, what books he may read or what films he may watch. Our whole constitutional heritage rebels at the thought of giving government the power to control men's minds".

Media law covers an area of law which involves media of all types (TV, film, music, publishing, advertising, internet \& Facebook media, etc.), and stretches over various legal fields, including but not limited to publicity and privacy, to corporate or finance or, intellectual property. As defamatory false statements can lead to legal liability, all criminal statutes punish false statements in areas of concern to the courts or agencies.

\section{Conclusion}

Free speech is meaningless unless it has room to breathe. The United States and India almost have parallel free speech provisions in their Constitutions. Article 19(1) (a) of Indian constitution corresponds to the First Amendment of the US Constitution which says, "congress shall make no law... abridging the freedom of speech or of the press". However, the provisions within the US Constitution have two notable features

a) Freedom of press is specifically mentioned therein;

b) No restrictions are mentioned on the freedom of speech. Within the famous case Justice Bhagwati stated [53]", the fundamental right to the freedom of speech and expression enshrined in our constitution is based on Amendment I of the Constitution of the United States and it would be therefore legitimate and proper to refer to those decisions of the Supreme Court of the United States of America in order to appreciate the true nature, scope and extent of this right in spite of the warning administered by this court against use of American and other cases." While similarities are in their constitutional provisions, the United States and India have their own unique jurisprudence on freedom of speech. It is important to notice that false statements made honestly are equally a part of freedom of speech. The supreme court of India applied the famous doctrine of New York Times $v$ Sullivan standard of American constitutional law against public officials. Accordingly, statements made against persons in the public eye can't be considered defamatory unless they were made with "actual malice". The proviso of freedom of speech and restrictions are the result of that way of thinking, and this is the Indian way on the contrary American's have own way on freedom of speech and expression.

In conclusion Mahatma Gandhi says, "One of the objects of a newspaper is to understand the popular feeling and give expression to it, another is to arouse among the people certain desirable sentiments, and the third is the fearlessness to expose popular defects." As like diverse method, media (print \& electronic, papers \& magazines, Radio \& Television, Internet \& social Media) is the medium or instrument of storing or communicating information as the 'Fourth Estate' or the watchdog of the public affairs, informing the society and vice versa, acts as the forum to advocate the views of the society at immense to at the rudder of public affairs.

\section{References}

1. Jalal-Din MR (1273) $13^{\text {th }}$-century Persian muslim poet, jurist, theologian, and Sufi mystic.

2. Doyle A, Blaze S, (1894) In the Memoirs of Sherlock Holmes investigating the disappearance of a race horse, 
Holmes deduces from the watchdog's failure to bark that the horse was taken by his trainer with whom the dog was familiar.

3. Madison J (1800) Report on the Virginia Resolutions, reprinted in 5 The Founders Constitution, In: Kurland $\mathrm{P}$, et al. (Eds.), sovereignty of the people and elective nature of government requires freedom of the press, pp: 142-147.

4. (1976) Nebraska Press Association v. Stuart 427 U.S. 539.

5. The state courts were de jure subordinate to the Supreme Court in Federal matters; they retained a great measure of de facto independence.

6. (1976) Nebraska Press Association v. Stuart 427 U.S. 539.

7. Madison MV (1803) 5 U.S. 137. The case resulted from a petition to the Supreme Court by William Marbury, who had been appointed Justice of the Peace in the District of Columbia by President John Adams but his appointment papers was not delivered by the new Secretary of State James Madison. The Court, with John Marshall as Chief Justice, found firstly that Madison's refusal to deliver the commission was both illegal and remediable. Chief Justice Marshall wrote the opinion of the court. In deciding whether Marbury had a remedy, Marshall stated: "The Government of the United States has been emphatically termed a government of laws, and not of men. It will certainly cease to deserve this high appellation if the laws furnish no remedy for the violation of a vested legal right." One of the key legal principles on which Marbury relies is the notion that for every violation of a vested legal right, there must be a legal remedy. Marshall next described two distinct types of Executive actions: political actions, where the official can exercise discretion, and purely ministerial functions, where the official is legally required to do something. Marshall found that delivering the appointment to Marbury was a purely ministerial function required by law, and therefore, the law provided him a remedy.

8. Chemerinsky E (2010) Constitutional Law: Principles and Policies Newyork: Aspen's Introduction to Law Series, pp: 203.

9. (2021) The Daily Star.

10. (1791) It was adopted on December 15, as one of the ten amendments that constitute the Bill of Rights.

11. (2020) The Google memo is a reminder that we generally don't have free speech at work". The Washington Post.
Archived from the original.

12. (1947) Everson v. Board of Education, 330 U.S.1.

13. Driesbach DL, Jefferson T (2002) The Wall of Separation between Church and State, NYU Press 2002, Unpaginated.

14. AIR 2015 SC 1523,

15. (2019) almost four years later, the Supreme Court was presented with new litigation based on findings that the Singhal $v$. Union of India ruling was not being properly implemented. The Internet Freedom Foundation published a study in November 2018 on the continued use of the Section which found about 65 to 70 cases cumulatively in different legal databases and that fresh cases were being registered in police stations, investigated and thereafter, considered by lower Courts.

16. Rajagopal R (1995) State of Madras, AIR 264.

17. In the American Supreme Court case of New York Times $v$ Sullivan, to Indian law. The Sullivan Rule (whose evolution in the American Civil Rights movement was traced by Swaminathan J.) is based on the recognition that if free speech, and especially journalistic speech, is to survive, it must have "breathing space." In other words, mere inaccuracies will not subject the writer to defamation, unless it is shown that the writer either knew that they were making false statements, or made them with "reckless disregard" for whether they were true or false.

18. (1985) Indian Express Newspapers (Bombay) Private Ltd. v. Union of India, 2 S.C.R. 287.

19. Khan v. State of West Bengal, WP 5326(W)/2020.

20. (2010) Indirect Tax Practitioners Assn. v R.K. Jain 8 SCC 281.

21. Interestingly, the judges found both Mr. Sibal and Mr. Jain not only not guilty of contempt of court but as having done real public service, each in his own way, as an advocate and as a journalist.

22. (1992) R.A.V. v. City of St. Paul, 505 U.S. 377.

23. Id. at 391.

24. (1942) Chaplinsky v. New Hampshirem, 315 U.S. 568.

25. (1969) Watts v. United States, 394 U.S, pp: 705-708.

26. (2003) 394 U.S. at 708. In Virginia v. Black, 538 U.S. 343, 359 the Court, citing Watts, upheld a statute that outlawed cross burnings done with the intent to intimidate. A cross burning done as "a statement of ideology, a symbol 
of group solidarity," or "in movies such as Mississippi Burning," however, would be protected speech, pp: 365366.

27. (1982) NAACP v. Claiborne Hardware Co., 458 U.S. 886.

28. 458 U.S. at 927.

29. (1919) Schenck v. United States, 249 U.S. 47.

30. Schenck and Baer were convicted of violating this law and appealed on the grounds that the statute violated the First Amendment. The question was to US Supreme Court, did Schenck's conviction under the Espionage Act for criticizing the draft violate his First Amendment right to freedom of speech?.

31. (1989) 491 U.S. 397. Flag burning constitutes symbolic speech that is protected by the First Amendment.

32. (1992) R.A.V. v. City of St. Paul, 505 U.S, pp: 377-383.

33. 505 U.S. at 384.

34. Id. 505 U.S. at 391 (1993) On the other hand, the First Amendment permits enhancement of a criminal penalty based on the defendant's motive in selecting a victim of a particular race. Wisconsin v. Mitchell, 508 U.S. 476. The law has long recognized motive as a permissible element in sentencing, the Court noted. Id. at 485. It distinguished R.A.V. as involving a limitation on speech rather than conduct, and because the state might permissibly conclude that bias-inspired crimes inflict greater societal harm than do non-bias inspired crimes (e.g., they are more likely to provoke retaliatory crimes). Id. at 487-88. See generally Laurence H. Tribe, The Mystery of Motive, Private and Public: Some Notes Inspired by the Problems of Hate Crime and Animal Sacrifice, 1993 SUP. CT. REV. 1.

35. (2003) Virginia v. Black, 538 U.S. 343.

36. (2003) 538 U.S. 343. A plurality held, however, that a statute may not presume, from the fact that a defendant burned a cross, that he had intent to intimidate. The state must prove that he did, as "a burning cross is not always intended to intimidate," but may constitute a constitutionally protected expression of opinion pp: 365-366.

37. 538 U.S., pp; 362,363.

38. 538 U.S. at 1-2.

39. (1966) Rosenblatt v. Baer, 383 U.S., pp: 75-85.

40. (1964) Louisiana GV, 379 U.S. 64, involved charges that judges were inefficient, took excessive vacations, opposed official investigations of vice, and were possibly subject to "racketeer influences." The Court rejected an attempted distinction that these criticisms were not of the manner in which the judges conducted their courts but were personal attacks upon their integrity and honesty. "Of course, any criticism of the manner in which a public official performs his duties will tend to affect his private, as well as his public, reputation. The publicofficial rule protects the paramount public interest in a free flow of information to the people concerning public officials, their servants. To this end, anything which might touch on an official's fitness for office is relevant. Few personal attributes are more germane to fitness for office than dishonesty, malfeasance, or improper motivation, even though these characteristics may also affect the official's private character", pp: 76-77.

41. Sullivan V (1964) 376 U.S. 254, was a landmark decision of the US Supreme Court ruling that the freedom of speech protections in the First Amendment to the U.S. Constitution restrict the ability of American public officials to sue for defamation. New York Times.

42. Justice Black wrote, "Only a free and unrestrained press can effectively expose deception in government".

43. Robert Welch GV (1974) 418 U.S. 323, was a landmark decision of the US Supreme Court establishing the standard of First Amendment protection against defamation claims brought by private individuals.

44. (1986) Philadelphia Newspapers v. Hepps, 475 U.S. 767.

45. 475 U.S. at 779 n. 4. Justice Brennan added a brief concurring opinion expressing his view that such a distinction is untenable, pp: 780 .

46. Sullivan V (1964) 376 U.S. 254, 280; Garrison v. Louisiana, 379 U.S., pp: 64-78.

47. (1974) Cantrell v. Forest City Publishing Co., New York Times 419 U.S, p: 245-252.

48. Thompson AV (1968) 390 U.S. 727; Beckley Newspapers Corp. v. Hanks, 389 U.S. 81. (1967) A finding of "highly unreasonable conduct constituting an extreme departure from the standards of investigation and reporting ordinarily adhered to by responsible publishers" is alone insufficient to establish actual malice. (1989) Harte-Hanks Communications v. Connaughton, 491 U.S. 657 (nonetheless upholding the lower court's finding of actual malice based on the "entire record"), pp: 730-733.

49. Robert Welch GV (1974) Inc., 418 U.S. 323, 331-332; (1964) Beckley Newspapers Corp. v. Hanks, 389 U.S. 8183. (1967) See New York Times Co. v. Sullivan, 376 U.S. 


\section{Annals of Bioethics \& Clinical Applications}

254, 285-86 ("convincing clarity"). (1986) A corollary is that the issue on motion for summary judgment in a New York Times case is whether the evidence is such that a reasonable jury might find that actual malice has been shown with convincing clarity. Anderson v. Liberty Lobby, 477 U.S. 242.

50. (1986) Philadelphia Newspapers v. Hepps, 475 U.S. 767 (leaving open the issue of what "quantity" or standard of proof must be met).

51. (1988) Hustler Magazine, Inc. v. Falwell, 485 U.S. 46.

52. United States v. Alvarez, 567 U.S., No. 11-210.

53. (1985) Express Newspapers (Private) Ltd. v. Union of India, 2 S.C.R, 287. 